\title{
The substantiation of differentiated therapy of the combined disgormonal pathology of reproductive organs in women of reproductive age with comorbid conditions
}

\author{
S.O.Shurpyak \\ Danylo Halytskyy Lviv National Medical University
}

\begin{abstract}
The objective: substantiation of the differentiated therapeutic approaches to the treatment of the combined dyshormonal pathology of the reproductive organs, taking into account the comorbidity of the patients.

Materials and methods. The study involved 300 women of reproductive age (20 - 42 years, an average of $29.9 \pm 5.6$ years). The examination included ultrasonographic examination of the pelvic organs, mammary glands, thyroid gland, determination of the levels of pituitary tropic hormones and ovarian steroid hormones, thyroid hormones, antibodies to thyroperoxidase, serum levels $25(\mathrm{OH}) \mathrm{D}$.

Results. Obesity of varying degrees was observed in $31.0 \%$ of the patients examined. The prevalence of autoimmune thyroiditis in patients with a dyshormonal pathology of the reproductive system was $36.0 \%$, and subclinical hypothyroidism was diagnosed in $21.3 \%$ of women, but among patients with autoimmune thyroiditis, the incidence of subclinical hypothyroidism was $59.3 \%$ with $3.7 \%$ of manifest hypothyroidism. Insufficiency of vitamin $D$ was detected in $34.0 \%$ of patients with dyshormonal pathology, vitamin $D$ deficiency in $44.3 \%$, severe deficit in $21.7 \%$.

Conclusions. The use of complex differentiated pharmacotherapy for treatment of combin dyshormonal pathology of reproductive organs with correction of comorbid states allows to achieve a higher efficacy in comparison with usual practice (normalization of MCs $97.2 \%$ at $\mathbf{7 3 . 3 \%}$, reduction of pain syndrome $94.7 \%$ at $\mathbf{6 0 . 6} \%$ and cyclic mastodynia $-93,9 \%$ at $\mathbf{4 3 , 9 \%}$, reduction of vegetative-vascular and nonspecific symptoms $-94,8 \pm 3,9 \%$ at $24,3 \pm 16,7 \%$ ), to reduce the frequency of relapses during 6 months of observation from $14,5 \%$ to $4.1 \%$ $(\mathrm{p}=0.0128)$, to achieve the desired pregnancy without stimulants and the ART and ovulation in $64.1 \%$ of patients compared with $30.6 \%$ $(\mathrm{p}=\mathbf{0 . 0 0 7 9 )}$ in case of usual practice.

Keywords: combined dyshormonal pathology of reproductive organs, comorbidity, hormonal therapy, thyroid dysfunction, obesity, vitamin D.
\end{abstract}

\section{Обґрунтування диференційованої терапії поєднаної дисгормональної патології репродуктивних органів у жінок репродуктивного віку з коморбідними станами \\ C.O. Шурпяк}

Мета дослідження: обгрунтування диференційованих терапевтичних підходів у лікуванні комбінованої дисгормональної патології репродуктивних органів з урахуванням коморбідності хворих.

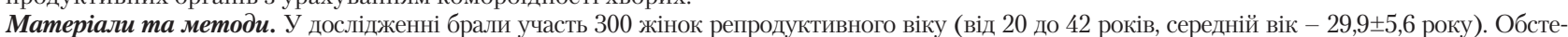
ження включало ультрасонографічне дослідження органів малого таза, грудних залоз, щитоподібної залози, визначення рівнів тропних гормонів гіпофіза та стероїдних гормонів яєчників, гормонів щитоподібної залози, антитіл до тиреопероксидази, сироваткового рівня 25 (ОН) D.

Результати. Ожиріння різного ступеня відзначали у 31,0\% обстежених. Поширеність аутоімунного тиреоїдиту у пацієнток з дисгормональною патологією репродуктивної системи становила $36,0 \%$, а субклінічний гіпотиреоз діагностували у $21,3 \%$ жінок, однак серед пацієнтів 3 аутоімунним тиреоїдитом частота субклінічного гіпотиреозу зростала до 59,3\% порівняно у 3,7\% проявів маніфестного гіпотиреозу. Недостатність вітаміну D виявлена у 34,0\% пацієнток з дисгормональною патологією, дефіцит вітаміну D - у 44,3\%, виражений дефіцит - у 21,7\%.

Заключення. Застосування комплексної диференційованої фармакотерапії для лікування комбінованої дисгормональної патології репродуктивних органів з корекцією коморбідних станів дозволяє досягти більш високої ефективності порівняно зі звичайною практикою (нормалізація МC - 97,2\% проти 73,3\% при звичайній практиці, зниження больового синдрому - 94,7\% проти 60,6\% та циклічна мастодинія - 93,9\% проти

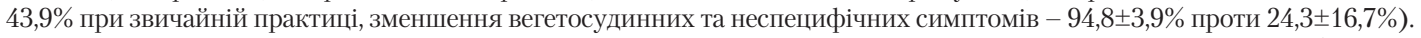

Застосована терапія дозволила досягти зменшення частоти рецидивів протягом 6 міс спостереження до 4,1\% та досягнення бажаної вагітності без стимуляції овуляції та АРТ у $64,1 \%$ пацієнток порівняно з $30,6 \%$ (p=0,0079) у разі застосування рутинної практики.

Ключові слова: комбінована дисгормональна патологія репродуктивних органів, коморбідність, гормональна терапія, дисфункиія щитоподібної залози, ожиріння, вітамін D.

\section{Обоснование дифференцированной терапии сочетанной дисгормональной патологии репродуктивных органов у женщин репродуктивного возраста с коморбидными состояниями C.A. Шурпяк}

Цель исследования: обоснование дифференцированных терапевтических подходов в лечении комбинированной дисгормональной патологии репродуктивных органов с учетом коморбидности больных.

Maтериалы и методы. В исследовании приняли участие 300 женщин репродуктивного возраста (от 20 до 42 лет, средний возраст -

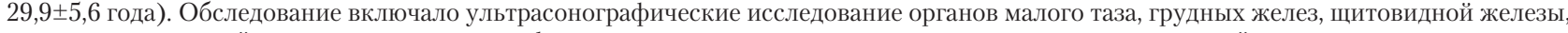
определение уровней тропных гормонов гипофиза и стероидных гормонов яичников, гормонов щитовидной железы, антител к тиреопероксидазе, сывороточного уровня $25(\mathrm{OH}) \mathrm{D}$.

Результаты. Ожирение различной степени отмечали у 31,0\% обследованных. Распространенность аутоиммунного тиреоидита у пациенток с дисгормональной патологией репродуктивной системы составляла $36,0 \%$, а субклинический гипотериоз диагностировали у $21,3 \%$ женщин, однако среди пациенток с аутоиммунным тиреоидитом частота развития субклинического гипотериоза возрастала до 59,3\% по сравнению с 3,7\% проявлений манифестного гипотиреоза. Недостаточность витамина D обнаружена у $34,0 \%$ пациенток с дисгормональной патологией, дефицит витамина D - у 44,3\%, выраженный дефицит - у 21,7\%. 
Заключение. Применение комплексной дифференцированной фармакотерапии для лечения комбинированной дисгормональной патологии репродуктивных органов с коррекцией коморбидных состояний позволяет достичь более высокой эффективности по сравнению с обычной практикой (нормализация МС - 97,2\% по сравнению с 73,3\% при обычной практике, снижение болевого синдрома - 94,7\% по сравнению с 60,6\% и циклическая мастодиния - 93,9\% по сравнению с 43,9\% при обычной практике, уменьшение вегетососудистых и не-

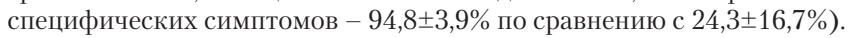

Данная терапия позволила достичь уменьшения частоты рецидивов в течение 6 мес наблюдения до 4,1\% и достижения желаемой беременности без стимуляции овуляции и АРТ у 64,1\% пациенток по сравнению с 30,6\% (р=0,0079) в случае применения рутинной практики.

Ключевъе слова: комбинированная дисгормональная патология репродуктивных органов, коморбидность, гормональная терапия, дисфункиия щитовидной железы, ожирение, витамин D.

$\mathrm{B}$ nign, combined dyshormonal diseases of the female reproductive system occupy a leading place in the structure of the general gynecologic morbidity [1]. The urgency of the problem is associated with the high prevalence of the combined pathology in the female population, significant rejuvenation of patients, adverse immediate and long-term consequences, frequent development on the background of comorbid conditions, which are presented by pathology thyroid gland (primarily hypothyroidism) and vitamin D deficiency [2, 3, 4]. Dyshormonal combined (uterine myoma, endometrial hyperplasia, adenomyosis, endometriosis, fibrocystic breast disease) pathology is characterized by more severe clinical manifestations, difficulties in diagnosing and selecting of optimal therapeutic tactics, increasing risk of malignancy, significantly worsens quality of life, and also increases the cost treatment. The key problems of the combined dyshormonal pathology, which require an effective solution, are uterine bleeding, pain syndrome (dysmenorrhea, dyspareunia, chronic pelvic pain), infertility and miscarriage $[2,5]$. Combined pathology usually leads to infertility and requires recourse to assisted reproductive technologies.

At the heart of the combined dyshormonal proliferative diseases of the female sexual sphere lies the commonality of etiology and key pathogenetic mechanisms (hormonal, inflammatory, molecular-genetic, etc.). Among the causes of the prevalence of hormone-dependent diseases of the reproductive organs in economically developed countries are the features of reproductive behavior, stresses, metabolic disorders, genetic predisposition, thyroid dysfunction, chronic inflammatory diseases of the genital organs, impaired liver function, intestinal function, environmental factors and lifestyle. Complex hormonal relationships that occur in women with thyroid dysfunction, create the preconditions for the emergence of not only monotopichnih hyperplastic processes, but also simultaneous lesions of the majority of hormonedependent reproductive organs $[2,6]$.

Low level of vitamin D is considered as an independent predictor of the formation and progression of obesity, insulin resistance, PCOS, increased risk of endometriosis, uterine leiomyoma [7, 8, 9]. D-Hormone affects the reproductive organs directly, by binding to receptors (VDR), and indirectly through stimulation of steroid hormone synthesis and other effects. Antiproliferative and cell differentiation-stimulating activity of vitamin D suggests its role in the development and suppression of proliferative processes in a number of organs, including reproductive (breast, ovaries, etc.) [1, 7, 10]. In some analysis based on epidemiological studies have shown a decrease of $25-35 \%$ of malignant tumors of different localizations risk at a concentration of $25(\mathrm{OH}) \mathrm{D} 30 \mathrm{ng} / \mathrm{ml}[7,11]$.

Management of patients with combined dyshormonal pathology presents significant difficulties starting with the differential diagnosis. And the possibilities of drug treatment are limited by imperfection of information about pathogenesis, routine approach to the choice of methods, the lack of a clear evidence base and an extensive list of contraindications to hormone therapy [1, 2, 6, 12]. The ineffectiveness of therapy causes a high incidence of surgical interventions, which is associated with a loss of fertility, risks to life and health. In this regard, early diagnosis, the ability to predict individual risk for progression of disease, personification of therapeutic approaches with regard to comorbidity remains an urgent problem. The problem of comorbidity - the simultaneous presence of the pathology of two or more organs or systems of the body, has been receiving increasing attention in recent years. Despite the variety of definitions of comorbidity, which is presented in the literature, the most appropriate is the definition in which, under the comorbid for a particular pathology, we mean violations that occur in this pathology more often than in the population and have some common etiological or pathogenetic mechanisms $[13,14]$. Comorbidity can manifest as type of synthropy (simultaneous damage to organs and systems under the influence of such pathogenetic factors) or interference (the occurrence of one disease under the influence of another) [14].

The influence of comorbid pathology on clinical manifestations, diagnosis, treatment and prognosis of many diseases is individual, but it is generally recognized that the interaction of diseases, age and pathomorphosis leads to pathogenetic features of pathology, including the reproductive system, complicates diagnosis, selection of optimal treatment technologies and negatively affects quality of patients life. Comorbidity is a serious aspect of reproductive health disorders and rehabilitation requires changing diagnostic and therapeutic approaches from disease-centered approach to patient-centered approach based on an integral assessment of the patient [15]. Such approaches should include the diagnosis and management of patients, taking into account the main aspects of life, risk factors, existing diseases and quality of life, and predicting of treatment effectiveness should be based on age grading, medical history, features of clinical manifestations, evaluation of quality of life and reproductive plans of patients, which led to the purpose of our work.

The objective: substantiate the differentiated therapeutic approaches to treatment of combined dyshormonal pathology of reproductive organs, taking into account the comorbidity of patients.

\section{MATERIALS AND METHODS}

The study involved 300 women of reproductive age (20-42 years, an average of $29.9 \pm 5.6$ years), residents of the Lviv region, with verified combined dyshormonal pathology of the reproductive organs. The study was conducted in accordance with the main provisions of the ICH GCP and the Helsinki Declaration of the World Medical Association «Ethical principles of medical research involving human subjects» $(1964,2008)$, the Council of Europe Convention on Human Rights and Biomedicine (2007) with the positive conclusion of the Commission on bioethics of Danylo Halytskyi Lviv National Medical University (protocol No.2 from 26.02.2018).

Complex examination included ultrasonographic (US) examination of the pelvic organs, mammary glands, thyroid gland, determination of pituitary hormone levels (FSH, LH, prolactin, TSH) and ovarian steroid hormones (estradiol, progesterone, free testosterone index, AMG) in the dynamics of menstrual flow cycle (MC), thyroid hormones (free T3 and T4), antibodies to tiroperoxidase (ATPO), serum level of $25(\mathrm{OH})$ D. Diagnosis of endometrium pathology (hyperplasia, endometrial polyps) was based on the data from US, hysteroscopy, morphological and immunohistochemical examination of the material obtained with biopsy or fractional curettage of the uterine cavity, in the same time diagnosis of external endometriosis, adenomyosis, uterine leiomyoma based on data set from US, diagnostic / operative laparoscopy, metrosalpingography.

The criteria for inclusion in the study were reproductive age, confirmed combined dyshormonal proliferative pathology of the reproductive organs, absence of severe extragenital pathology, in- 
formed consent for participation in the study, exclusion criteria oncological pathology of any site, infiltrative retrocervical, genital endometriosis, submucous leiomyoma of the uterus, presence of myomas more than $5 \mathrm{~cm}$ in diameter, infertility of tubal genesis, acute urogenital infection, psychic disorder.The nature of the combined dyshormonal pathology found in patients is shown in Table 1.

Morphological and immunohistochemical study of endometrial biopsies, shows pathology of the endometrium in 239 (79.7\%) women (Table 1). Endometrial hyperplasia (WHO classification, 2014) was diagnosed in 189 (79.1\%) cases, endometrial polyps were detected in 50 (20.9\%) women. Chronic endometritis was verified immunohistochemically (detection of CD 138+) in 107 (35.7\%) cases: in 21 (42.0\%) cases in patients with endometrial polyps, in 69 (36.5\%) women with endometrial hyperplasia and in $17(27.9 \%)$ of 61 patients without other endometrial pathology.

To assess the effectiveness of the proposed therapeutic and rehabilitation system the patients were randomized into two groups.

I (main) group included 180 women who received treatment according to the developed differentiated program with correction of comorbid conditions. The II group (comparisons) included 120 patients receiving treatment according to common practice. 50 healthy women without somatic and gynecological pathology were included in the control group.

The primary point of effectiveness was the reduction of clinical manifestations (dysmenorrhea, disorders of $\mathrm{MC}$, mastalgia, mastodynia), a secondary point of effectiveness - the duration of the disease-free period after completion of therapy and tertiary point - the onset of a desired pregnancy (observation for 6 to 12 months).

\section{RESULTS AND DISCUSSION}

The average age of the women in group I was $25.3 \pm 2.2$ years (20; 29 years), group II $-35.3 \pm 3.3$ years $(30,42$ years) (Table 1$)$. $76(25.3 \%)$ and $52(17.3 \%)$ patients complained only for violation of MC or pain syndrome, respectively. In most cases (172; $57.3 \%$ ), there was a combination of complaints about violations of the MC, dysmenorrhea, dyspraunia. Cyclic mastalgia and mastodynia (engorgement, increase in volume, increased sensitivity and tenderness during palpation of the mammary glands in the second phase of the MC) disturbed 155 (51.7\%) patients.

Among the violations of menstrual function, which were noted by $248(82.7 \%)$ women, most often were observed irregular menstruation ( $81 ; 32.7 \%)$, hyperpolymenorrhea $(77 ; 31.5 \%)$, meager menstruation $(28 ; 11.3 \%)$, smearing spotting before / after menstruation disturbed 62 (26.2\%) women. Among the other complaints expressed by the patients, weight gain for the last 2 years $(137 ; 45.7 \%)$, a constant feeling of fatigue $(99,33.0 \%)$, periodic headaches $(89 ; 29.7 \%)$, violation sleep $(77 ; 25.7 \%)$, sensation of «puffiness» $(56 ; 18.7 \%)$, cosmetic problems (hair loss, dry skin) (61; 20.3\%), vegetative-vascular disorders (tachycardia, numbness and «coldness» of the hands and feet) $(65 ; 21.7 \%)$

The reproductive function was not realized in 151 (50.3\%) patients: 30 (19.9\%) had not previously planned a pregnancy, pri- mary infertility occurred in 52 (34.4\%) cases, in 69 (45.7\%) - secondary infertility. In the anamnesis of 67 (22.3\%) women with a history of habitual miscarriage, were observed term births (7; $10.5 \%)$, early (51; 76.1\%) and late $(23 ; 34.3 \%)$ spontaneous miscarriages, very early premature births (22;32.8\%).

Assessment of mammary gland showed no changes ( 1 category according to the BI-RADS system) in 122 (40.7\%) patients, dyshormonal benign breast dysplasia (BI-RADS category 2) in $158(52.7 \%)$ women, and in $20(11.2 \%)$ patients Category 3 in the BI-RADS system (the second examination was scheduled after 6 months).

Fatty tissue is an important link in the metabolism of sex steroids, which affects the functioning of the reproductive system. Obesity can be considered as a comorbid state in relation to the dyshormonal proliferative pathology of the reproductive system, because excess of fatty tissue, insulin resistance and hyperestrogenia are significant risk factors for the development of proliferative processes [16]. Excess body weight (average BMI $27.7 \pm 1.1 \mathrm{~kg} / \mathrm{m}^{2}$ ) was in $97(32.3 \%)$ patients, obesity of the I degree (average BMI $33.3 \pm 0.9 \mathrm{~kg} / \mathrm{m}^{2}$ ) - in $68(22.7 \%)$, obesity of the 2nd degree (average BMI $38.6 \pm 1.4 \mathrm{~kg} /$ $\left.\mathrm{m}^{2}\right)$ in $25(8.3 \%)$ women, overal obesity of different degree was observed in $93(31.0 \%)$ of the examined patients (Table 2 ).

In this case, the waist circumference (a marker of excess visceral fat that is associated with the presence of insulin resistance) averaged $94.3 \pm 2.7 \mathrm{~cm}$ in $55.5 \%$ of obese patients, and the ratio of the circumference of the waist to the hip circumference was $0.87 \pm 0,04$.

Analysis of clinical studies in which the relationship between dysfunction of the thyroid gland and reproductive function of women has been studied allows us to state that underestimation influences of thyroid gland function in the diagnosis and treatment of gynecological pathology leads to an increase reproductive disorders in women and a decrease quality of life [17].

According to the literature, a positive reaction to A-TPO is an early predictor of hypothyroidism in cases where the TSH level is above $2.0 \mathrm{mMO} / \mathrm{L}$ [18].

According to the recommendations of the American Thyroid Association (ATA) (2017) [20], all patients who are preparing for pregnancy, or become pregnant again, and have risk factors should undergo clinical examination with the determination of TSH levels.

The frequency of detection of diffuse goiter I-II st. did not differ between clinical groups $(\mathrm{p}>0.05)$, while the prevalence of autoimmune thyroiditis in patients with dyshormonal pathology of the reproductive system was $36.0 \%$, and subclinical hypothyroidism was diagnosed in $64(21.3 \%)$ women (Table 2 ), in relation to patients with autoimmune thyroiditis (108 cases), the incidence of subclinical hypothyroidism was $59.3 \%$ with $3.7 \%$ of manifest hypothyroidism.

When hypothyroidism changes the metabolism of estrogens with the change of normal 2-hydroxylation occurs predominantly 16-hydroxylation with the formation of an aggressive inducer of proliferation of $16 \alpha$-hydroxyestrone (16 $\alpha$-ONE1), which is one of the pathogenetic links in the development of combined dysgormonal proliferative diseases of the reproductive organs and requires consideration in the development of therapeutic measures .

Characteristics of the combined pathology in women of examined cohort

Table 1

\begin{tabular}{|c|c|c|}
\hline The nature of the combined pathology & $\begin{array}{l}\text { absolute numbers, } \\
(\%)\end{array}$ & $\begin{array}{c}\text { Combination with } \\
\text { mastopathy } \\
\text { (absolute numbers, \%) }\end{array}$ \\
\hline External genital endometriosis and uterine leiomyoma & $27(9,0)$ & $16(59,3)$ \\
\hline External genital endometriosis, uterine leiomyoma and endometrial pathology & $48(16,0)$ & $27(56,3)$ \\
\hline External genital endometriosis and endometrial pathology & $43(14,3)$ & $23(53,5)$ \\
\hline Adenomyosis and uterine leiomyoma & $34(11,3)$ & $20(58,8)$ \\
\hline Adenomyosis, uterine leiomyoma and endometrial pathology & $63(21,0)$ & $37(58,7)$ \\
\hline Uterine leiomyoma and endometrial pathology & $85(28,3)$ & $55(64,7)$ \\
\hline Total $(n)$ & 300 & $178(59,3 \%)$ \\
\hline
\end{tabular}


A study of vitamin D sufficiency showed that level in the serum with average value $34.5 \pm 3.8 \mathrm{ng} / \mathrm{ml}$ of $25(\mathrm{OH})$ D occurred in $31(62.0 \%)$ women in the control group and $22(7.3 \%)$ in group with dyshormonal pathology of reproductive organs $(p<0.0001)$. According to the experts of the International Endocrinology Association, vitamin D deficiency is defined as serum levels of $25(\mathrm{OH}) \mathrm{D}$ less than $20 \mathrm{ng} / \mathrm{ml}(50 \mathrm{nmol} / \mathrm{L})$, and the optimal level of $25(\mathrm{OH}) \mathrm{D}$ is more than $30 \mathrm{ng} / \mathrm{ml}(75 \mathrm{nmol} / \mathrm{l})$ [21, 22]. However, there are a number of studies demonstrating significant health and quality of life benefits of higher level of $25(\mathrm{OH}) \mathrm{D}$. According to the recommendations of «The Vitamin D Society» Canadian society of vitamin D experts (http://www vitamindsociety.org/ benefits.php), an optimal level of $25(\mathrm{OH}) \mathrm{D}$ in the blood serum should be considered as $40-60 \mathrm{ng} / \mathrm{ml}(100-150 \mathrm{nmol} / \mathrm{l})$ [22, 23].

In the cohort of the women who were examined, the optimal level of $25(\mathrm{OH}) \mathrm{D}$ in the blood serum $(36.7 \pm 5.3 \mathrm{ng} / \mathrm{ml})$ was detected only in 17 (34.0\%) of women in the control group (Table 3 ).

Vitamin D deficiency with an average levels of $25(\mathrm{OH}) \mathrm{D}$ in serum $22.6 \pm 1.3 \mathrm{ng} / \mathrm{ml}$ was found in $102(34.0 \%)$ of the $300 \mathrm{sur}-$ veyed patients, and in $30(60.0 \%)$ women in the control group $(\mathrm{p}=0.0005)$. Deficiency of vitamin D $(25(\mathrm{OH}) \mathrm{D}$ in serum with average levels $13.8 \pm 4.6 \mathrm{ng} / \mathrm{ml}$ ) in women with no gynecological and somatic pathology was detected only in $3(6.0 \%)$ cases, whereas in women with concomitant dyshormonal benign proliferative disorders of reproductive organs vitamin $\mathrm{D}$ deficiency occurred in $133(44.3 \%)$ cases $(\mathrm{p}<0.0001)$, and severe deficiency $(25(\mathrm{OH}) \mathrm{D}$ $6.34 \pm 1.39 \mathrm{ng} / \mathrm{ml}$ was detected in $65(21.7 \%)$ women in group I with absence in the control group, that is a strong indicator of importance of sufficient provision of the body with vitamin D for the normal functioning of the female reproductive system.

At present, there are no uniform standards for pathogenetic therapy of combined benign proliferative pathology of reproduc- tive organs and benign breast diseases, especially with regard to comorbid pathology. For treatment, a wide range of drugs with different directionality is used.

Considering all the above, we justified and tested differentiated pharmacotherapy of combined dyshormonal proliferative diseases of reproductive organs, depending on the patients reproductive plans.

According to the latest recommendations, subclinical hypothyroidism in women who plan pregnancy should be treated with levothyroxine, while the goal of treatment is to achieve a TSH concentration of $<2.5 \mathrm{mU} / 1[19,24]$. Although there is currently insufficient evidence that levothyroxine therapy improves the fertility of euthyroid ATPO-positive women, levothyroxine may be used, starting at a dose of 25-50 $\mu \mathrm{g} /$ day for this category of patients with a history of fetal loss. If TSH $>4,2 \mathrm{mU} / \mathrm{L}$, and there is no symptoms of hypothyroidism and patient have unrealized reproductive plans, therapy with levothyroxine is indicated, since the optimal level of TSH for pregnancy planning with subclinical and manifest hypothyroidism is $0.4-2.0 \mathrm{mU} / 1$ [20].

In I (main) group, the complex of differentiated pharmacotherapy assumed several successive stages. Therapy of the first stage in patients with chronic endometritis and in all - after intrauterine interventions, suggested the use of antibacterial therapy and a drugs that improves the microcirculation in pelvic organs and contributes increasing concentration of antibiotics in the focus of chronic inflammation. Antibacterial therapy consisted of sequential administration of doxycycline (7 days at $200 \mathrm{mg} /$ day in two doses) and josamycin (7 days at $1.0 \mathrm{~g} /$ day in two divided doses) was carried out in the first phase of MC against the background of 9-day rectal suppositories «Dispetase» (one suppository contains 15000 IU streptokinase and 1250 IU streptodornase) according to the official scheme.

Patients with subclinical hypothyroidism received levothyroxine in a daily dose of $100 \mathrm{mcg}$, euthyroid patients with a

Clinical characteristics of the examined women

Table 2

\begin{tabular}{|c|c|c|c|c|}
\hline \multirow{2}{*}{ Features } & \multicolumn{4}{|c|}{ Groups } \\
\cline { 2 - 5 } & $\begin{array}{c}\text { Control, } \\
\mathbf{n = 5 0}\end{array}$ & $\begin{array}{c}\text { All, } \\
\mathbf{n = 3 0 0}\end{array}$ & $\begin{array}{c}\text { Main group, } \\
\mathbf{n = 1 8 0}\end{array}$ & $\begin{array}{c}\text { Comparison group, } \\
\mathbf{n = 1 2 0}\end{array}$ \\
\hline Average age (years) M $\pm \mathrm{m}$ & $\begin{array}{c}31,0 \pm 6,1 \\
(20 ; 41)\end{array}$ & $30,7 \pm 4,3(22 ; 42)$ & $\begin{array}{c}31,98 \pm 5,5 \\
(22 ; 40)\end{array}$ & $\begin{array}{c}30,8 \pm 5,2 \\
(22 ; 40)\end{array}$ \\
\hline Normal weight & $42(84,0)$ & $110(36,7)$ & $65(36,1)$ & $45(37,5)$ \\
\hline Excess body weight & $8(16,0)$ & $97(32,3)$ & $59(32,8)$ & $38(31,7)$ \\
\hline Obesity of the I degree & - & $68(22,7)$ & $41(22,8)$ & $27(22,5)$ \\
\hline Obesity of the 2nd degree & - & $25(8,3)$ & $15(8,3)$ & $10(8,3)$ \\
\hline Diffusive goiter I-II st. & $18(36,0)$ & $119(39,7)$ & $69(38,3)$ & $50(41,7)$ \\
\hline Autoimmune thyroiditis & - & $108(36,0)$ & $63(35,0)$ & $45(37,5)$ \\
\hline Subclinical hypothyroidism & - & $64(21,3)$ & $39(21,7)$ & $25(20,8)$ \\
\hline Manifest hypothyroidism & - & $11(3,7)$ & $7(3,9)$ & $4(3,3)$ \\
\hline Infertility & - & $151(50,3)$ & $89(49,4)$ & $62(51,7)$ \\
\hline Habitual miscarriage & - & $67(22,3)$ & $41(22,8)$ & $26(21,7)$ \\
\hline
\end{tabular}

Characterization of D-status of examined women by 25 (OH) D level in serum

\begin{tabular}{|c|c|c|c|c|}
\hline \multirow{2}{*}{$\begin{array}{l}\text { Level of } 25(\mathrm{OH}) \mathrm{D} \text { in the } \\
\text { serum }(\mathrm{ng} / \mathrm{ml})\end{array}$} & \multicolumn{4}{|c|}{ Groups (absolute numbers, \%) } \\
\hline & $\begin{array}{c}\text { Control, } \\
\mathrm{n}=\mathbf{5 0}\end{array}$ & $\begin{array}{l}\text { Dyshormonal pathology, } \\
\qquad \mathrm{n}=\mathbf{3 0 0}\end{array}$ & $\begin{array}{l}\text { Group I, } \\
n=180\end{array}$ & $\begin{array}{l}\text { Group II, } \\
n=120\end{array}$ \\
\hline More than $30 \mathrm{ng} / \mathrm{ml}$ & $17(34,0)$ & - & - & - \\
\hline $29-20 \mathrm{ng} / \mathrm{ml}$ & $30(60,0)$ & $\begin{array}{l}102(34,0) \\
p=0,0005\end{array}$ & $54(30,0)$ & $48(40,0)$ \\
\hline $19-10 \mathrm{ng} / \mathrm{ml}$ & $3(6,0)$ & $\begin{array}{l}133(44,3) \\
p<0,0001\end{array}$ & $67(37,2)$ & $66(55,0)$ \\
\hline Less than $10 \mathrm{ng} / \mathrm{ml}$ & - & $65(21,7)$ & $34(18,9)$ & $31(25,8)$ \\
\hline
\end{tabular}


history of reproductive loss with a high concentration of A-TPO received levothyroxine at $50 \mathrm{mcg}$ / day. All patients with vitamin D insufficiency and deficiency received cholecalciferol (aqueous solution for oral administration) in a daily dose of $4000 \mathrm{IU}$, in patients with severe vitamin D deficiency, the daily dose of cholecalciferol was 8000 IU. Control of TSH and $25(\mathrm{OH})$ D levels in the blood serum was performed after 2 months with correction, of a dose of levothyroxine and cholecalciferol if necessary. The target parameters of the therapy were achievement of a TSH level of $0.4-2.0 \mathrm{mU} / \mathrm{L}$ and a level of $25(\mathrm{OH}) \mathrm{D} 40-50 \mathrm{ng} / \mathrm{ml}$.

At the second stage (duration of 3-6 months depending on reproductive plans), with continued taking of levothyroxine and cholecalciferol, Levokarnitin was administered as a metabolic and antioxidant therapy at a daily dose of $2 \mathrm{~g}(20 \mathrm{ml})$ in 2 doses 30 minutes before meals (course 30 days). Patients with mastopathy received a drugs with antiproliferative effect, containing epigallocatechin3-gallate, 3,3-diindolylmethane and a vinex extract of the sacred.

From the second stage, differentiated gestagenotherapy began. Patients with unrealized reproductive plans (89) received micronized progesterone vaginally and sublingually from 14 to 26 days of MC at daily dose of $400 \mathrm{mg}$. Special attention should be paid to the use of micronized progesterone in the third menstrual cycle on the background of rectal suppositories with streptokinase and streptodornase (from 14 to 23 days MC for 1 suppository twice a day). Women who did not plan pregnancy received dienogest $2 \mathrm{mg} /$ day for 6 months (55 patients with genital endometriosis), the remaining patients (36 patients with uterine leiomyoma and adenomyosis) received $\mathrm{COC}$ containing $0.02 \mathrm{mg}$ of ethinylestradiol and $0.15 \mathrm{mg}$ desogestrel in the prolonged mode $63+7$.

Patients of group II received similar therapy with gestagens and COC, only 4 (3.3\%) women with manifest hypothyroidism (125 $\mu \mathrm{g} /$ day) received levothyroxine. All patients were given an aqueous solution of cholecalciferol at $1000 \mathrm{U} /$ day.

The analysis of the primary efficacy point showed a faster and more effective reduction of clinical manifestations and complaints of patients in the main (I) group (Table 4).

The analysis of the obtained data showed that efficacy of proposed differential individualized therapy (primary efficacy point) for normalization of $\mathrm{MC}$ was $97.2 \%$ in the main group at $73.3 \%$ in
Table 4

Primary point of effectiveness in a cohort of examined patients (absolute numbers, \%)

\begin{tabular}{|c|c|c|c|c|c|}
\hline \multirow{3}{*}{$\begin{array}{l}\text { Clinical } \\
\text { manifestations } \\
\text { of dyshormonal } \\
\text { combined } \\
\text { pathology }\end{array}$} & \multicolumn{5}{|c|}{ Groups } \\
\hline & \multirow{2}{*}{$\begin{array}{l}\text { The entire } \\
\text { cohort, } \\
\mathrm{n}=300 \\
\begin{array}{c}\text { Before } \\
\text { treatment }\end{array}\end{array}$} & \multicolumn{2}{|c|}{ Main group, $n=180$} & \multicolumn{2}{|c|}{$\begin{array}{c}\text { Comparison group, } \\
n=120\end{array}$} \\
\hline & & $\begin{array}{l}\text { Before } \\
\text { treatment }\end{array}$ & $\begin{array}{c}\text { After } \\
\text { treatment }\end{array}$ & $\begin{array}{l}\text { Before } \\
\text { treatment }\end{array}$ & $\begin{array}{c}\text { After } \\
\text { treatment }\end{array}$ \\
\hline $\begin{array}{l}\text { MC disorders } \\
\text { (isolated) }\end{array}$ & $76(25,3)$ & $43(23,9)$ & 0 & $33(27,5)$ & $\begin{array}{c}5(4,2) \\
P_{1}=0,0679\end{array}$ \\
\hline $\begin{array}{l}\text { The combination of } \\
\text { MC disorders and } \\
\text { pain syndrome }\end{array}$ & $172(57,3)$ & $100(55,6)$ & $\begin{array}{c}4(2,2) \\
* P<0,0001\end{array}$ & $72(60,0)$ & $\begin{aligned} 23 & (19,2) \\
{ }^{*} P_{1} & =0,0001 \\
P 2 & =0,154\end{aligned}$ \\
\hline \multicolumn{6}{|c|}{ Of them: } \\
\hline Irregular MC & $81(32,7)$ & $48(26,7)$ & $0(0)$ & $33(27,5)$ & $\begin{array}{c}2(1,7) \\
P_{1}=0,0886\end{array}$ \\
\hline Hyperpolymenorrhea & $77(31,5)$ & $44(24,4)$ & $\begin{aligned} & 2(1,1) \\
\star & P=0,029\end{aligned}$ & $33(27,5)$ & $\begin{array}{c}10(8,3) \\
P_{1}=0,1131 \\
P_{2}=0,6046\end{array}$ \\
\hline Scanty menstruation & $28(11,3)$ & $17(9,4)$ & $0(0)$ & $11(9,2)$ & $\begin{array}{c}9(7,5) \\
P_{1}=0,8963\end{array}$ \\
\hline $\begin{array}{l}\text { Spotting before and } \\
\text { after menstruation }\end{array}$ & $62(26,2)$ & $34(18,9)$ & $\begin{array}{c}2(2,2) \\
P=0,1245\end{array}$ & $28(23,3)$ & $\begin{array}{c}7(5,8) \\
P_{1}=0,1629 \\
P_{2}=0,7395\end{array}$ \\
\hline $\begin{array}{l}\text { Pain syndrome } \\
\text { (isolated) }\end{array}$ & $52(17,3)$ & $31(17,2)$ & $\begin{array}{c}3(1,7) \\
P=0,1757\end{array}$ & $21(17,5)$ & $\begin{array}{c}14(11,6) \\
P_{1}=0,6312 \\
P_{2}=0,4373\end{array}$ \\
\hline $\begin{array}{l}\text { Cyclic mastalgia / } \\
\text { mastodynia }\end{array}$ & $155(51,7)$ & $98(54,4)$ & $\begin{array}{c}6(3,3) \\
* P<0,0001\end{array}$ & $57(47,5)$ & $\begin{array}{c}32(26,7) \\
{ }^{*} P_{1}=0,045 \\
{ }^{*} P_{2}=0,0378\end{array}$ \\
\hline $\begin{array}{l}\text { Vegetative-vascular } \\
\text { disorders }\end{array}$ & $65(21,7)$ & $39(21,7)$ & $\begin{array}{c}3(1,7) \\
* P=0,0387\end{array}$ & $26(21,7)$ & $\begin{array}{c}24(20,0) \\
P_{1}=0,8847 \\
P_{2}=0,1392\end{array}$ \\
\hline Headache & $89(29,7)$ & $50(27,8)$ & $\begin{array}{c}2(1,1) \\
\star P=0,029\end{array}$ & $39(32,5)$ & $\begin{array}{c}29(24,2) \\
\mathrm{P}_{1}=0,4547 \\
{ }^{*} \mathrm{P}_{2}=0,0401\end{array}$ \\
\hline $\begin{array}{c}\text { Feeling of fatigue } \\
\text { (permanent) }\end{array}$ & $99(33,0)$ & $56(31,1)$ & 0 & $43(35,8)$ & $\begin{array}{c}37(30,8) \\
P_{1}=0,6395\end{array}$ \\
\hline Sleep disorders & $77(25,7)$ & $44(24,4)$ & $\begin{array}{c}2(1,1) \\
* P=0,0293\end{array}$ & $33(27,5)$ & $\begin{array}{c}25(20,8) \\
P_{1}=0,5582 \\
P_{2}=0,1392\end{array}$ \\
\hline $\begin{array}{l}\text { Sensation of } \\
\text { «puffiness» }\end{array}$ & $56(18,7)$ & $33(18,3)$ & $\begin{array}{c}2(1,1) \\
P=0,0839\end{array}$ & $23(19,2)$ & $\begin{array}{c}21(17,5) \\
P_{1}=0,8868 \\
P_{2}=0,2228\end{array}$ \\
\hline Cosmetic problems & $61(20,3)$ & $37(20,5)$ & $\begin{array}{c}5(2,8) \\
* P=0,0482\end{array}$ & $24(20,0)$ & $\begin{array}{c}20(16,7) \\
P_{1}=0,7824 \\
P_{2}=0,2422\end{array}$ \\
\hline $\begin{array}{c}\text { Subclinical } \\
\text { hypothyroidism }\end{array}$ & $64(21,3)$ & $39(21,7)$ & $0(0)$ & $25(20,8)$ & $\begin{array}{c}9(7,5) \\
P_{1}=0,286\end{array}$ \\
\hline $\begin{array}{c}\text { Manifest } \\
\text { hypothyroidism }\end{array}$ & $11(3,7)$ & $7(3,9)$ & $0(0)$ & $4(3,3)$ & $0(0)$ \\
\hline
\end{tabular}

${ }^{*} \mathrm{P}$ - reliability of differences in the main (I) group before and after treatment

${ }^{*} \mathrm{P}_{1}$ - reliability of differences in the comparison group (II) before and after treatment

${ }^{*} \mathrm{P}_{2}$ - the difference between main group and comparison group after treatment the comparison group $(\mathrm{p}<0.0001)$, with respect to the pain syndrome reduction $-94.7 \%$ and $60.6 \%(\mathrm{p}<0.0001)$ respectively and cyclic mastodynia $-93.9 \%$ and $43.9 \%(p<0.0001)$ respectively. Even more significant was the reduction of vegetative-vascular and nonspecific symptoms $-94.8 \pm 3.9 \%$ in the main group and $24.3 \pm 16.7 \%$ in the comparison group $(\mathrm{p}=0.0001)$. 
After the completion of treatment, the thyroid function was improved, which was manifested by a successful correction of manifest hypothyroidism (100.0\% in both clinical groups), but if the establishment of a low normal level of TSH $(2.4 \pm 0.2 \mathrm{mIU} / \mathrm{L})$ in the main group was achieved in $100 \%$ of patients, in the comparison group progression of subclinical hypterosis was noted, which required correction of thyroid status with levothyroxine in the future.

The recurrence frequency for clinical manifestations of combined dyshormonal pathology of reproductive organs after 6 months followup after completion of therapy (secondary efficacy point) in the main group was $4.1 \%$ at $14.5 \%$ in the comparison group $(\mathrm{p}=0.0128)$.

Among 89 patients of I group with unrealized reproductive plans, the desired pregnancy (without ovulation stimulation and ART) (tertiary point of efficacy) during 12 months of follow-up was confirmed in $57(64.1 \%)$ of patients in the main group and $19(30.6 \%)$ in the group comparison $(\mathrm{p}=0.0079)$. All pregnancies finished by childbirth in term of 37-40 weeks by live newborns.

\section{CONCLUSIONS}

1. Patients with benign dyshormonal proliferative pathologies of reproductive organs are significantly more likely than healthy women have thyroid dysfunction, severe vitamin D deficiency, obesity, which, taking into account common pathogenetic aspects, allows to consider revealed violations as important comorbid conditions requiring adequate correction.

2. The use of complex differentiated pharmacotherapy of combined proliferative dyshormonal pathology of the reproductive organs, taking into account and correcting the comorbid states (dysfunction of the thyroid gland, excessive nutrition / obesity) allows to achieve a higher efficacy in comparison with usual practice (normalization of the MC $97.2 \%$ at $73.3 \%$, $\mathrm{p}<0.0001$, reduction of pain syndrome $94.7 \%$ at $60.6 \%$ and cyclic mastodynia $-93.9 \%$ at $43.9 \%(\mathrm{p}<0.0001)$, a decrease in vegetative-vascular and nonspecific symptoms $-94.8 \pm 3.9 \%$ at $24.3 \pm 16.7 \%, \mathrm{p}=0.0001$ respectively.

3. The use of differentiated pharmacotherapy of combined proliferative dyshormonal pathology allows to reduce the frequency of recurrences in clinical manifestations during 6 months of observation after therapy completion from $14.5 \%$ to $4.1 \%$ $(\mathrm{p}=0.0128)$ and reach the desired pregnancy without stimulation of ovulation and ART in 64,1\% of patients compared with $30.6 \%$ $(\mathrm{p}=0.0079)$ in normal practice.

\section{Information about the author}

Shurpyak Serhii Oleksandrovych - Lviv national medical University named Danylo Galitsky, 79010 , Lviv, 69 Pekarska str . E-mail: shurpyak_serhiy@yahoo.com

ORCID: 0000-0002-5445-6375

\section{Відомості про автора}

Шурпяк Сергій Олександрович - Львівський національний медичний університет імені Данила Галицького, 79010, м. Львів, вул. Пекарська, 69. E-mail: shurpyak_serhiy@yahoo.com

ORCID: 0000-0002-5445-6375

\section{Сведения об авторе}

Шурпяк Сергей Александрович - Львовский национальный медицинский университет имени Данила Галицкого, 79010, г. Львов, ул. Пекарская, 69. E-mail: shurpyak_serhiy@yahoo.com

ORCID: 0000-0002-5445-6375

\section{REFERENCES}

1. Kiselev VI, Sidorova IS, Unanyan AL, Muizhnek EL. Hyperplastic processes of the organs of the female reproductive system: theory and practice. M. Medpraktika-M, 2010: 468 p. (In Russ.). 2. Kryukova AA. Conservative treatment of the uterine hyperplastic processes against the background of thyroid pathology. Reproductive health of a woman. 2006; 2 (26): 93-96. (In Russ.).

3. Maruna P. Gynecological aspects of thyroid disorders. A review. Ceska Gynecol. 2006; 71 (4): 332-338.

4. Männistö $T$, Vääräsmäki $M$, Pouta $A$. et al. Thyroid dysfunction and autoantibodies during pregnancy as predictive factors of pregnancy complications and maternal morbidity in later life J. Clin. Endocrinol. Metab. 2010; 95(3): 1084-1094.

5. Chernukha GE, Dumanovskaya MR. Modern ideas about endometrial hyperplasia. Obstetrics and gynecology. 2013; 3: 26-32. (In Russ.)

6. Grigorenko AN. Hyperplasia of the endometrium: there are more questions than answers. Reproductive endocrinology. 2017; 3 (35): 31-43. (In Russ.)
7. Holick MF, Binkley NC, BischoffFerrari HA, Gordon CM. et al. Evaluation, treatment, and prevention of vitamin D deficiency: an Endocrine Society clinical practice guideline. J. Clin. Endocrinol. Metab. 2011; 96 (7): 1911-30.

8. Holick MF, Chen TC. Vitamin D deficiency: a worldwide problem with health consequences. The American journal of clinical nutrition. 2008; 87 (4):1080S1086S.

9. Mithal A, Wahl DA, Bonjour JP, et al. Global vitamin D status and determinants of hypovitaminosis D. Osteoporos Int. 2009; 20:1807-20.

10. Buggio L, Roncella E, Somigliana $E$, Vercellini $P$. Vitamin $D$ and benign gynaecological diseases: A critical analysis of the current evidence. Gynecol Endocrinol. 2015;16:1-5.

11. Palacios $C$, Gonzalez L. Is vitamin $D$ deficiency a major global public health problem? J Steroid Biochem Mol Biol. 2014;144.Pt A:138-145.

12. Radzinsky BE, Ordiyants IM, Maslennikova MN, Pavlova EA. Mammary glands and gynecological diseases: from the generality of pathogenetic views to practical solutions. Reproductive endocrinology. 2014; 2 (16): 72-80. (In Russ.) 13. Belyalov Fl. Twelve theses of comorbidity. Clinical medicine. 2009; 12: 6971. (In Russ.).

14. Gubanova GV, Belyaeva UN, Shemetova GN. Comorbid patient: stages of formation, risk factors and tactics of reference. Modern problems of science and education. 2015; 6: 10-13. (In Russ.).

15. van Weel C, Schellevis FG. Comorbidity and guidelines: conflicting interests. Lancet. 2006; 367: 550-551. 16. Shoelson SE, Herrero L, Naaz A. Obesity, inflammation, and insulin resistance. Gastroenterol. 2007;132:2169-2180.

17. Redmond GP. Thyroid dysfunction and women's reproductive health. Thyroid. 2004; 14 (1): 515

18. Walsh JP, Bremner AP, Feddema P. et al. Thyrotropin and thyroid antibodies as predictors of hypothyroidism: a 13year, longitudinal study of a communitybased cohort using current immunoassay techniques J. Clin. Endocrinol. Metab. 2010; 95(3): 1095-1104.
19. Brabant PG, Duntas L, Monzani F et al. Management of Subclinical Hypothyroidism 2013 ETA Guideline. Eur. Thyroid. J. 2013; 2: 215-228.

20. Alexander EK, Pearce EN, Brent GA, Brown RS, et al. 2017 Guidelines of the American Thyroid Association for the Diagnosis and Management of Thyroid Disease During Pregnancy and the Postpartum. Thyroid. 2017; 27 (3): 315-389. DOI: 10.1089 /thy.2016.0457.

21. Food and Drug Administration, HHS, et al. Food Labeling: Revision of the Nutrition and Supplement Facts Labels. Final rule. Federal Register. 2016; 81 (103): 33-741. URL https://www.federalregister.gov/documents/2016/05/27/2016-11867/foodlabeling-revisionof- the-nutrition-andsupplement-facts-labels\#h-127.

22. Hossein-Nezhad A., Holick M.F. Vitamin $D$ for health: a global perspective. Mayo Clin Proc. 2013; 88 (7): 720-55. 23. Holick MF. Vitamin D is not as toxic as was once thought: a historical and an up to-date perspective. Mayo Clin. Proc. 2015; 90: 561-4. 